\title{
Do transport costs have a differential effect on trade at the sectoral level?
}

\author{
Inmaculada Martínez-Zarzoso*, Eva Maía Pérez García** and Celestino Suárez-Burguet*** \\ * Instituto de Economía Internacional and Departamento de Economía, Universidad Jaume I, Castellon, \\ Spain and Ibero American Institute for Economic Research, Goettingen 12080, Germany \\ ** Instituto de Economía Internacional, Universidad de Valencia, Edificio Dep. Oriental 3-F12, Campus \\ dels Tarongers, 46022 and Fundación Valenciaport, Valencia, Spain
}

*** Instituto de Economía Internacional and Departamento de Economía, Universidad Jaume I, Campus del Riu Sec, 12080 Castellón, Spain

This article aims to analyse the determinants of transport costs and to investigate their influence in international trade with a sample of disaggregate trade data. First, we estimate a transport-cost function using cross-section data on maritime and overland transport for four sectors: agro-industry, ceramic tiles, motor vehicle parts and accessories, and electrical and mechanical household appliances, obtained from interviews held with Spanish exporters and logistics operators in 2001.

Second, we study the relationship between transport costs and trade and estimate the elasticity of trade with respect to transport costs for each sector. Important differences for high value- and low value-added sectors are observed. The trade-equation estimation shows that higher transport costs significantly deter trade, especially in high value-added sectors.

\section{Introduction}

Trade costs play a crucial role in models of international specialization and trade. Several authors have recently provided theoretical evidence supporting this view: Krugman (1991), Deardorff (1995), Henderson et al. (2001), Hummels et al. (2001), Venables and Limao (2002). Since recent liberalization processes have substantially reduced artificial trade costs, such as tariffs and nontariff barriers, nowadays, the importance of transport costs in relative terms is considerably higher than in the past decades. In most cases, there is no direct way of observing these transport costs between nations, and therefore indirect measurement and trade modelling must be relied upon in order to assess their relevance. Any accurate attempt to provide direct evidence of transport costs will contribute to the understanding of the determinants of these costs and will shed some light on the magnitude of the barriers that they generate.

In this article we investigate the determinants of transport costs and study the relationship between trade and transport costs in four Spanish exporting sectors. Our estimation proceeds in two parts.

We start with evidence on transport costs and their determinants, and then relate this evidence to the estimates of trade volumes. A major contribution of the article lies on the use of a data set consisting of primary data on shipment freight rates at firm level. The data was directly obtained from interviews held with exporters and logistic operators in the Spanish territory, as opposed to the more common measures taken from the national trade data sources, based on 'free on board'/'cost, insurance and freight' ratios (Hummels and Lugovskyy, 2003). A minor contribution is the construction of a new index to measure the infrastructure of a country, based on information for road transport. Finally, to our knowledge, only one paper $^{1}$ has examined the differential impact of transport costs on sectoral trade using survey data. A few papers used sectoral trade data to estimate the elasticity of trade with respect to transport costs, but they did only calculate an average elasticity for all sectors (Martinez-Zarzoso and Suarez-Burguet, 2005) or used secondary data (Hummels, 1999a).

\footnotetext{
${ }^{1}$ Martı'nez-Zarzoso et al. (2003) analysed the impact of transport cost on trade in the ceramic sector.
} 
Section II presents a literature review. Data and sources are described in Section III. In Section IV, a transport-cost function is estimated by using data on Spanish exports by sector. Section V presents and estimates a variant of the standard gravity model of trade. Section VI comments on the results of the empirical application and concludes.

\section{Literature Review}

In the recent economic literature there have been several attempts to measure transport costs directly or indirectly. Some authors used cif/fob2 ratios as a proxy for shipping costs (Radelet and Sachs, 1998; Baier and Bergstrand, 2001; Limao and Venables, 2001;). Since most importing countries report trade flows inclusive of freight and insurance (cif) and exporting countries report trade flows exclusive of freight and insurance (fob), transport costs can be calculated as the difference of both flows for the same aggregate trade. However, Hummels (1999b) showed that importer cif/fob ratios constructed from IMF sources are poor proxies for cross-sectional variation in transport costs and such a variable provides no information about changes over time or across sectors. Oguledo and Macphee (1994) also doubted the usefulness of cif/fob ratios from IMF sources as a proxy of transportation costs.

Hummels (1999a, b) used data on transport costs from various primary sources; including shipping price indices obtained from shipping trade journals (Appendix 2 in Hummels, 1999b), air freight prices gathered from survey data and freight rates (freight expenditures on imports) collected by customs agencies in United States, New Zealand and five Latin-American countries (Mercosur plus Chile).3 Hummels (1999a) classified the trade costs implied by trade flows into three different categories: explicit measured costs, given by tariffs and freight rates; costs associated with common proxy variables such as distance, sharing a language, sharing a border or being an island, and implied but unmeasured trade costs, given by geographical position, cultural ties or political stability. His results indicated that explicit measured costs were the most important component.

In addition to cif/fob ratios reported by IMF, Limao and Venables (2001) used shipping company quotes for the cost of transporting a standard container (40 feet) from Baltimore to 64 destinations. The authors pointed out that it is not clear how the experience of Baltimore generalized. Martínez-Zarzoso et al. (2003) used data on transportation costs obtained from interviews with logistic operators in the Spanish ceramic sector. They found import elasticities with respect to transport costs similar in magnitude to those found by Limao and Venables (2001).

Micco and Perez (2001) used data from the US Import Waterborne Databank (U.S. Department of Transportation), where transport cost is defined as 'the aggregate cost of all freight, insurance and other charges (excluding US import duties) incurred in bringing the merchandise from the port of exportation to the first port of entry in the US'. Sánchez et al. (2002) analysed data on maritime transport costs obtained from the International Transport Data Base (BTI). They focused on Latin American trade with North American Free Trade Area. Martinez-Zarzoso and Suarez-Burguet (2005) also used cif/fob ratios obtained from the BTI. Data from the BTI for transport costs include all modes and are defined as the expenditure on international freight and insurance. Freight rates are in general inclusive of loading costs. The main difference between these ratios and those reported by IMF is that the BTI data on imports at cif prices and imports at fob prices are obtained from the same reporting country. Since information is collected using identical methodology, the data are more reliable than the IMF rates. A second difference is that the data are disaggregated at three-digit level SITC. However, the authors estimated a single equation for all the sectors and obtained a trade elasticity with respect to transport costs of -2.30 .

\section{The Data}

The empirical application of this article is based on extensive fieldwork based on personal interviews with import/export and logistics managers at export companies (160 interviews) and freight forwarding agents

\footnotetext{
${ }^{2}$ Cif stands for 'cost, insurance and freight'; fob stands for 'free on board.'

${ }^{3}$ Hummels (1999a)
} 
(78 interviews). ${ }^{4}$ Four sectors were selected for analysis: agro-industry (wine, cereals, canned food and vegetable oils), ceramic tiles, motor vehicle parts and accessories and electrical and mechanical household appliances. The selection was made attempting to find sectors with differentiated transport needs. ${ }^{5}$ All four selected sectors are among the top 10 exporters, both in terms of weight and in terms of exported value, with the exception of household appliances (which only ranks among the top 10 exporters in terms of value). Agro-industrial products and ceramic tiles may be considered low value-added commodities - in comparison to motor vehicle parts and household appliances; these two goods showing a large weight-to-value ratio. On the other hand, motor vehicle parts and household appliances may be seen as high value-added products, while presenting a large volume-to-weight ratio. The particular features of these four commodities will allow an evaluation of the influence of variables such as distance, weight, volume, number of shipments, transit time, among others, on transport costs.

Aiming at building a database that would permit the specification and estimation of a transport cost/ trade model, 238 interviews were conducted in November 2001 among transport decision makers in the following 11 autonomous regions in Spain: Andalucí, Aragón, Cantabria, Castilla La Mancha, Catalunya, Comunidad Valenciana, La Rioja, Madrid, Murcia, Navarra and País Vasco - which are the most industrialized Spanish regions. Fieldwork conducted was based on personal interviews with import/export and logistics managers at export companies (160 interviews) and freight forwarding agents (78 interviews). The total of 1251 observations were compiled as a result of these 238 interviews, of which, 1028 were valid observations for the regressions. The distribution of interviews across sectors is shown in Table A3 in the Appendix and in Table A4, the destination countries for exports are listed.

From a statistical point of view, the collected sample is the representative of the studied population, and the results and conclusions should therefore be in line with those to be expected from the Spanish industrial structure. Detailed information, concerning the regional distribution of interviews carried out and averages of the variables, is shown in the Appendix in Tables A1 and A2, respectively.

With respect to sectoral exports, the interviewees did not directly report the value or quantity exported. They only indicated the percentage of exports directed to each foreign market. Therefore export data (quantity and value) were obtained from the database 'Spanish Foreign Trade Statistics' published by the Spanish Custom Agency for the different sectors under analysis. A careful matching of the export data and the transport-costs data were made at a high disaggregation level (8 digits). For illustration, Export codes at four digits and product descriptions are listed in Table A5 in the Appendix.

\section{Determinants of Transport Costs}

A number of authors have recently investigated the determinants of international transport costs. Estimates are given in Radelet and Sachs (1998), Hummels (1999a), Fink et al. (2002), Limao and Venables (2001), Micco and Pérez (2001), Kumar and Hoffmann (2002) and Sánchez et al. (2002). The explanatory variables used in their analysis are basically related to distance and connectivity, such as if countries are landlocked or if trading partners are neighbours and to country characteristics such as GDP per capita. Some of them focus on the impact of specific factors on transport costs, for example, Micco and Pérez (2001) and Sánchez et al. (2002) analyse the impact of port reform on transport costs and study the possible effects of port reform in Latin America. Fink et al. (2000) investigate how liberalization in trade and transport services leads to further reductions in transport costs, which in turn leads to a further promotion of trade in goods.

\footnotetext{
${ }^{4}$ See Appendix 3 for additional details of how the data were collected and from whom

${ }^{5}$ Given the complexity of studying all Spanish export trade flows, the aim of selecting four sectors was to achieve a significant overview of transport cost and trade determinants by researching a representative sample of the Spanish production framework.
} 
Kumar and Hoffmann (2002) consider the mutual relationship between the trade volumes, the transport costs and the quality of transport services. They find that the market for maritime transport services is growing and observe increased concentration in the maritime industry and, at the same time, more competition. Although transport unit costs decline, the incidence of the maritime transport costs in the final value of the good increases since many components are purchased internationally. The authors state that the strong relationship between trade and transport costs detected by Limao and Venables (2001) does not only reflect the elasticity of trade towards transport costs, but might be also reflecting the economies of scale through which higher volumes lead to lower costs of transport.

More evidence is needed at sector level and using primary sources, as most of the research has used aggregated data and secondary sources. In this line, we estimate a linear equation where transportation costs are specified as a function of distance, mode of transport, infrastructure, port efficiency, transit time, number of shipments, average size of shipments and various dummies. Distance has been widely used in gravity equations as a proxy for transport costs since a higher distance implies a longer journey and a higher associated cost and it is very difficult to collect transport-costs data of good quality. A differential relationship is observed in our data between transport cost and distance for road and sea transport, indicating that as distance grows road transport costs always increase, but sea transport costs only increase for shorter distances and then slightly decrease. This feature will be considered in the transportcosts equation by adding interaction variables (distance*mode) and (distance square*mode). Infrastructure in the exporting country and in the transit countries has also proved to be an important determinant of transport costs (Limao and Venables, 2001). Infrastructure measures are related to the quality of communications and transport infrastructure that countries possess. Transit time, average number of shipments per year and average size of the shipments in each sector are also taken into account as explanatory variables. Transit time may be a proxy for the quality of the service, whereas average number of shipments (frequency) and average size of shipments could be indicating high volumes of exports going through a particular route, pointing towards the existence of economies of scale.

The costs of the journey between countries are influenced by other geographic characteristics such as adjacency, being an island or being landlocked. Countries sharing a common border usually have better communication network connections and more possibilities for back-hauling, due to the fact that they trade more extensively, allowing for fixed costs to be shared over two trips and thereby reducing total costs. Some cultural similarities, such as a common language, could also be considered as determinants of transport costs, assuming that this facilitates trade transactions. Furthermore, being landlocked normally adds extra costs, because it means that the commodities being traded must be transported on a relatively more expensive and on average longer leg by road and need to face customs formalities twice, at the landlocked country and at the country were the port of loading/unloading is located. We added a dummy according to the mode of transport. The basic specification is given by:

$$
\begin{aligned}
\ln \mathrm{TC}_{i j k}= & \alpha_{0}+\alpha_{1} \ln D_{i j}+\alpha_{2}\left(\ln D_{i j}\right)^{2} \\
& +\alpha_{3} \operatorname{Mode}+\alpha_{4} \ln I N F_{i j} \\
& +\alpha_{5} \ln P E_{j}^{*} \operatorname{Mode}+\alpha_{6} \ln \mathrm{TT}_{i j} \\
& +\alpha_{7} \ln \mathrm{NS}_{i j k}+\alpha_{8} \ln \mathrm{AS}_{i j k}+\mu_{i j k}
\end{aligned}
$$

where TCijk denotes transport costs incurred when transporting product $\mathrm{k}$ from province $\mathrm{i}$ in Spain to country j, Dij denotes distance from the city of origin in Spain (i) to destination j, Mode is a dummy that takes the value one when products are transported by sea and zero when goods are transported by road, INFij denotes the quality of roads that connect $\mathrm{i}$ and $\mathrm{j}, \mathrm{PEj}$ denotes port efficiency in country $\mathrm{j}$, TTij is transit time from door to door, NSijk is the average number of hipments per year for a specific company to a particular destination and for sector $\mathrm{k}$, ASijk is the average size of the shipments for a given route and for sector $\mathrm{k}$. All the variables except ummies are in natural logs. _ijk denotes the error term that is assumed to be independently normally distributed.

The variable INFij is constructed ${ }^{6}$ for road transport. We consider the quality of roads in the ountries that have to be crossed scaled by the area of the countries and weighted by the number of borders:

\footnotetext{
${ }^{6}$ The variable $\mathrm{INF}_{\mathrm{ij}}$ has been initially constructed as an index (by taking information on roads, paved roads, railroads and number of telephone lines) differentiating between importer and transit countries' infrastructure as explanatory variables of transport costs. This index is comparable to that of Limao and Venables (2001), but opposite signed.
} 


$$
\mathrm{INF}_{i j}=\frac{m_{i} \mathrm{PR}_{i} / A_{i}+\sum m_{t} \mathrm{PR}_{t} / A_{t}+m_{j} \mathrm{PR}_{j} / A_{j}}{\mathrm{NB}_{i j}}
$$

where NBij depends on the number of borders that have to be crossed to reach the final destination.

Table 1. Determinants of transport costs

\begin{tabular}{|c|c|c|c|c|c|c|c|c|}
\hline \multirow{2}{*}{$\frac{\text { Variable }}{\text { Constant term }}$} & \multicolumn{2}{|c|}{ Agro-industry } & \multicolumn{2}{|l|}{ Ceramics } & \multicolumn{2}{|c|}{ Household appliances } & \multicolumn{2}{|c|}{ Vehicle parts } \\
\hline & $-2.56^{* * *}$ & $(-3.42)$ & -0.88 & $(-1.25)$ & $1.52^{* *}$ & $(2.07)$ & $3.58 * * *$ & $(3.24)$ \\
\hline Distance & $0.61^{* * *}$ & $(9.33)$ & $0.69^{* * *}$ & $(8.13)$ & $0.46^{* * *}$ & $(3.37)$ & $0.31 * *$ & (1.93) \\
\hline Distance $*$ mode & $1.94^{*}$ & $(1.22)$ & -0.86 & $(-1.31)$ & $-0.55^{* * *}$ & (4.54) & $-0.36^{* * *}$ & $(-2.47)$ \\
\hline Distance square*mode & $-0.18 * *$ & $(-2.29)$ & 0.01 & $(0.24)$ & - & & - & \\
\hline Mode & -4.23 & $(-0.88)$ & $5.38^{* *}$ & $(2.02)$ & $3.49 * * *$ & $(3.26)$ & $2.68 * *$ & $(2.30)$ \\
\hline Infrastructure & $-0.17^{* * *}$ & $(-2.58)$ & $-0.23^{* * *}$ & $(-3.78)$ & 0.02 & $(0.15)$ & -0.09 & $(0.88)$ \\
\hline Port efficiency $*$ mode & $-0.33^{* * *}$ & $(-2.98)$ & -0.008 & $(-0.07)$ & 0.10 & $(0.44)$ & -0.21 & $(-1.14)$ \\
\hline Transit time & $0.10^{* * *}$ & $(2.45)$ & $0.12 * * *$ & $(2.87)$ & $0.18 *$ & $(1.45)$ & -0.05 & $(-0.65)$ \\
\hline Number of shipments & $-0.05^{* * *}$ & $(-4.85)$ & $-0.02^{*}$ & $(-1.77)$ & $-0025^{* *}$ & $(-0.84)$ & $-0.08 * * *$ & $(-3.83)$ \\
\hline Average size of shipments & $-0.15^{* * *}$ & $(-12.55)$ & $-0.08^{* * * *}$ & $(-7.61)$ & $-0.23^{* * *}$ & $(-7.76)$ & $-0.15^{* * * *}$ & $(-4.63)$ \\
\hline Cereals & $0.26^{* *}$ & $(2.08)$ & - & & - & & - & \\
\hline Wine & $0.19 * *$ & $(2.08)$ & - & & - & & - & \\
\hline Canned food & -0.02 & $(-0.19)$ & - & & - & & - & \\
\hline Oil & $0.25^{* * *}$ & $(2.93)$ & - & & - & & - & \\
\hline Adjacency & $-0.18^{* * *}$ & $(-4.13)$ & 0.03 & $(0.73)$ & $-0.18^{*}$ & $(-1.77)$ & $-0.26^{* * *}$ & $(-2.88)$ \\
\hline Island & $-0.10^{* * *}$ & $(-2.74)$ & 0.02 & $(0.81)$ & -0.12 & $(-1.05)$ & -0.02 & $(-0.18)$ \\
\hline Landlocked & 0.02 & $(0.23)$ & 0.03 & $(0.25)$ & $0.29 * *$ & $(2.49)$ & $0.35^{* *}$ & $(2.48)$ \\
\hline Number of observations & 668 & & 548 & & 318 & & 450 & \\
\hline$R^{2}$ & 0.66 & & 0.55 & & 0.47 & & 0.34 & \\
\hline Adjusted $R^{2}$ & 0.65 & & 0.54 & & 0.450 & & 0.32 & \\
\hline SE of regression & 0.330 & & 0.316 & & 0.613 & & 0.626 & \\
\hline
\end{tabular}

Notes: All variables are for the year 2001. ${ }^{* *}, * *$ and $*$ indicate significance at 1,5 and $10 \%$, respectively. $T$ statistics, based on White Heteroskedasticity-Consistent SE, are in brackets. The dependent variable is the natural log of transport costs measured in $€$ per tonne. All the variables except dummies are in natural logs. Mode is a dummy variable that takes the value one when the good is transported by sea and zero otherwise. Distance*mode is an interaction variable that takes a positive value (distance in kilometer between trading cities) when the good is transported by sea and zero otherwise. Port efficiency*mode is another interaction variable that takes a positive value when the good is transported by sea and zero otherwise.

It takes the value 1 for transport inside the $\mathrm{EU}$, the value increases by 0.10 when a border is crossed. $\mathrm{Ai}$, At and $\mathrm{Aj}$ are the areas of the countries which infrastructure is considered. PRi,PRt and PRj are kilometres of paved road in countries $i, t$ and $j ; t$ denotes transit countries. $m$ takes a value between zero and one according to the quality of roads in a given country (equals 0.75 for paved roads and 1 for motorways).

A summary of the estimation results is shown in Table 1. Different regressions were run for each sector since we could not accept equality of slopes for the independent variables in a pooled regression. The number of cross sections is higher for agro-industry (668) and ceramic products (548) than for household appliances (318) and vehicle parts (450). We tried several specifications, by testing for the significance of the explanatory variables. First, for comparative purposes we estimated a model with only distance and mode variables. ${ }^{7}$ A number of conclusions were reached. First, the distance coefficient has the expected positive sign showing that a $1 \%$ increase in distance increases transport costs by approximately $0.25 \%$ for low value-added sectors and by $0.13 \%$ for high value-added sectors. This magnitude is slightly lower than those found in other studies for different commodities. Hummels (1999) finds commodity specific distance coefficients clustered between 0.2 and 0.3, and Kumar and Hoffmann (2002) found a distance elasticity of 0.24 for the case of Intra-Latin American trade. Second, the mode dummy has a negative and significant coefficient, showing that transport costs for a given distance are lower for sea transport.

\footnotetext{
${ }^{7}$ Results are available upon request.
} 


\section{Determinants of transport costs}

When infrastructure variables are added in the model, they show a statistically significant coefficient with the expected negative sign for agro-industry and ceramics (low value-added sectors). A $1 \%$ improvement in the infrastructure of the destination country lowers transport costs by $0.20 \%$ on average. However, we find that infrastructure variables are in most cases not significant at conventional levels for high valueadded sectors: household appliances and vehicle parts. A plausible reason could be that these products are generally sold to the most developed European countries and these countries already have the highest levels of infrastructure quality. Additionally, the port efficiency variable is only significant and negative signed for agro-industry and in some cases for vehicle parts.

The estimated coefficient for the variable transit time shows that for agro-industry, ceramics and household appliances at $1 \%$ increase in the time of transit increases the cost by $0.15 \%$. The number of shipments and the average size of shipments are also shown to be significant and negative signed almost always (apart from the number of shipments for household appliances). This result may be indicating the existence of economies of scale, as a higher frequency or a greater size of shipment indicates that more trade goes through a particular route. However, the first variable may also be (indirectly) showing a better quality of the service offered by a particular route.

The inclusion of additional variables improves the fit of the regression since the adjusted R2 considerably increases corroborating the importance of infrastructure, transit time, number of shipments and average size of the shipments in determining transport costs for these sectors.

The adjacency dummy presents a negative and significant coefficient for three out of four sectors, showing that being neighbours reduces transport cost by $0.25 \%$. The dummy island is only significant for agro-industry and negative signed and the landlocked dummy is significant and positive signed for high value-added sectors. Dummy variable coefficients are not significant for the adjacency, language, island and landlocked dummies for the ceramic sector. This result validates earlier findings obtained in Martínez-Zarzoso et al. (2003) with a different data set for the same sector.

Finally, since the levels of freight rates might be affected not only by the mode of transport, but also by the distance elasticities, we introduce interaction variables (Mode*Distance).

The (Mode*Distance) coefficient is significant for all the sectors apart from ceramics. For the agroindustry sectors a second interaction variable (Distance square*Mode) is found to be statistically significant and negative signed, whereas the (Mode*Distance) coefficient is significant and positive signed. In this particular case, the results indicate that transport costs are increasing with distance for road transport; however for sea transport, costs are increasing only for shorter distances and decreasing for longer distances. Finally, for high value-added sectors the (Mode*Distance) coefficient presents a negative sign indicating that unit cost is decreasing with distance when the mode of transport is sea.

Summing up, we find that distance is a significant determinant of transport, costs; it has a higher impact for road transport than for sea transport and higher sea distances reduce transport costs in the agroindustry sector. Infrastructure variables are only significant for low value-added sectors (agro-industry and ceramics) and economies of scale in transport are present in all the sectors (proxied by average size and number of shipments). Concerning geographical dummies, interior countries face higher transport costs, whereas neighbour countries have lower transport costs. These two dummies are nonsignificant only for the ceramic sector.

\section{Trade Volumes}

In order to assess the relative importance of transport costs on trade, we need an appropriate theoretical framework. In recent years, the gravity model of trade has become the workhorse of international trade. ${ }^{8}$ From the large empirical literature in this field (see Oguledo and Macphee, 1994; for a survey of the literature), it is commonly accepted that gravity models explain well the bilateral trade patterns.

\footnotetext{
${ }^{8}$ Bayoumi and Eichengreen (1997, p. 142).
} 
We estimate a demand model for sectoral exports, based on a log-linear form of a gravity equation augmented with infrastructure variables. The model is specified as,

$$
\begin{aligned}
\ln X_{i j k}= & \beta_{0}+\beta_{1} \ln Y_{j}+\beta_{2} \ln D_{i j}+\beta_{3} \ln \mathrm{INF}_{i j}+\beta_{4} L d l \\
& +\beta_{5} \text { lang }+\beta_{6} I s I+\beta_{7} A d j+\varepsilon_{i j k}
\end{aligned}
$$

where $\mathrm{ln}$ denotes natural logarithms, $\mathrm{Yj}$ is the income in the destination market, Dij is distance from the province of origin to the destination market, INFij is the infrastructure variable defined previously, Ldl is a dummy for landlocked countries, Lang is a dummy for countries sharing the same language, Isl takes the value 1 when countries are islands and zero otherwise, and Adj takes the value 1 when countries share the same border and zero otherwise.

The model is jointly estimated for the four sectors with 2001 data. Pooled estimation with fixed effects was the best option since most of the explanatory variables are common across sectors and we only found statistical differences for the distance variable.

We perform Ordinary Least Squares estimation on the double log specification as given by Equation 3 .

\section{Determinants of sectoral exports}

Table 2 shows our results. Model 1 presents the OLS results for the baseline case, which excludes infrastructure variables and dummies. The standard regressors are income and distance variables. The coefficient on income is positive, as expected, and the income elasticity is 0.64 . The coefficient on distance is negative signed and highly significant.

In Model 2 the mode variable is added, showing a negative and significant coefficient, indicating that exports are higher if the goods are transported by road. In Model 3 we add the list of dummies that might influence exports. The landlocked dummy presents the expected negative sign showing that when a country has no sea-shore, exports to this country are $282 \%$ [exp(1.34)-1] lower than for a coastal country. The adjacency dummy presents a slightly significant positive signed coefficient, showing that neighbour countries trade $249 \%$ [exp(1.25)-1] more than nonneighbour countries. The island dummy presents a positive sign and the coefficient is also significant. The remaining variable coefficients have the same sign and similar magnitude as before, apart from the distance coefficient that decreases in magnitude. In Model 4 the infrastructure variable is added showing a positive and significant coefficient and high elasticity (3.46). We can see how the distance coefficient is not significant, as it shows the correct sign but a smaller magnitude (-0.63) when compared to Model 3. The fit of the equation is also better ( $\mathrm{R}$ increases a 0.05). In Model 5 we estimate different distance coefficients ${ }^{9}$ for each sector to allow for more flexibility in the model. We find that the distance coefficient is significant and with the expected negative sign for the agriculture and food sector and for vehicle parts, whereas it is lower in magnitude and insignificant for ceramics and household appliances. The sectoral dummies are not significant in Model 5.

Finally, Model 6 was estimated in order to check whether there were problems of reverse causation between exports and income. The model was estimated using the two stages least square estimator. Two additional variables are selected as instruments for the income variable: the area of the country and the distance to the Equator. In this model the distance specific coefficients are significant and above unity for high value-added sectors, whereas the coefficient is smaller and less significant for low value-added sectors. ${ }^{10}$

In order to compare our results with those obtained by Limao and Venables (2001), using estimates from Model 6, we will be able to link trade volumes to transport costs by calculating parameter $\tau$, the elasticity of trade volumes with respect to transport costs. We use the coefficients of significant variables (at least

\footnotetext{
${ }^{9}$ We used a Wald test to test for the equality of slopes in the sectoral-distance elasticities. The test is included at the end of Table 2 and the result indicates rejection of the null hypothesis (equality of slopes)

10 Sectoral dummies are excluded since they were nonsignificant in Model 5.
} 
for some sectors) included in both the transport-cost and the importdemand equations. We focus on the distance variable. Table 3 presents the parameter estimates for this variable and the ratio of the trade elasticities to the freight elasticities indicates the elasticity of trade with respect to transport costs.

\section{Estimates of export elasticity with respect to transport costs}

For comparative purposes, we estimated $\tau$ in the same way as Limao and Venables (2001). They calculated implied elasticities of -2.95 on the basis of distance. However, as aggregated data was used as opposed to the sector data that we use, our results are more specific and not directly comparable to Limao and Venables (2001). We obtain export elasticities with respect to transport costs implied by the point estimates on the basis of distance of -1.52 and -1.20 for low value-added sectors and -2.82 and -3.93 for high value-added sectors. According to our calculations low value-added sectors seem to have considerably lower export elasticity with respect to transport cost than high value-added sectors, pointing towards a lower incidence of transport costs in trade for the former. Vehicle parts present the highest elasticity, indicating that a decrease of $1 \%$ in transport costs would increase exports by $3.93 \%$. An explanation of the sectoral differences in trade-transport-cost elasticities could be related to searching costs and consumer risk aversion as determinants of exports. These two factors are relatively more important for differentiated products than for homogeneous products. Huang (2006) shows that distance deters trade to a higher extent for differentiated commodities than for homogeneous goods. In fact, Table 2 in the appendix shows that average distances travelled for high value-added products are lower than for low value-added products. A second explanation could be based on Yeats' (1977; p.469) findings. He noted that some processed products have a tendency to be more difficult to handle, more fragile or even subject to higher insurance costs and these factors contribute to increased transport costs for differentiated products. A higher unitary transport cost and a lower distance travelled for differentiated products than for more homogeneous products could give rise to a higher trade-transport-cost elasticities for the former. Finally, the elasticity of trade with respect to transport costs is also related to the elasticity of substitution among products. Since the elasticity of substitution is higher for processed products, that could also explain that trade is more elastic with respect to transport costs for this type of goods, that have more closer substitutes than homogeneous products (Hummels, 1999a).

\begin{tabular}{|c|c|c|c|c|c|c|c|c|c|c|c|c|}
\hline Variable & Model 1 & & Model 2 & & Model 3 & & Model 4 & & Model 5 & & Model 6 & \\
\hline Constant term & $23.28 * * *$ & $(6.01)$ & $19.98^{* * * *}$ & $(5.81)$ & $19.46^{* * * *}$ & $(3.80)$ & $14.72^{* *}$ & $(4.35)$ & $25.92^{* * *}$ & $(4.50)$ & $21.4^{* *}$ & $(4.40)$ \\
\hline Importer income & $0.64^{* * * *}$ & $(5.52)$ & $0.64^{* * * *}$ & $(5.63)$ & $0.51^{* * * *}$ & $(4.23)$ & $0.27 * *$ & $(2.08)$ & $0.23^{* *}$ & $(1.80)$ & $0.57^{* * *}$ & (2.69) \\
\hline Distance & $-1.66^{* * *}$ & $(-4.17)$ & $-1.15^{* *}$ & $(-2.64)$ & $-0.98^{* *}$ & $(-2.27)$ & $-0.63^{*}$ & $(-1.52)$ & - & & - & \\
\hline Distance*mode & - & & - & & - & & - & & - & & 0.51 & $(0.66)$ \\
\hline Distance*dummyagro & - & & - & & - & & - & & $-0.55^{*}$ & $(0.32)$ & $-0.94^{*}$ & $(-1.51)$ \\
\hline Distance*dummycer & - & & - & & - & & - & & -0.34 & $(0.54)$ & -0.84 & $(-1.34)$ \\
\hline Distance $*$ dummyha & - & & - & & - & & - & & -1.00 & $(-1.04)$ & $-1.31 * *$ & $(-2.05)$ \\
\hline Distance $*$ dummyauto & - & & - & & - & & - & & $-1.57^{* * *}$ & $(-2.06)$ & $-1.22^{* *}$ & $(-1.93)$ \\
\hline Mode & - & & $-1.43^{* *}$ & $(-3.66)$ & $-1.61^{* * *}$ & $(-4.13)$ & $-1.49^{* * *}$ & $(-2.35)$ & $-2.22^{* * *}$ & $(-5.30)$ & -5.99 & $(0.98)$ \\
\hline Infrastructure & - & & - & & - & & $3.46^{* * *}$ & $(4.97)$ & $3.52^{* * * *}$ & $(5.67)$ & $2.62^{* * *}$ & $(3.42)$ \\
\hline Landlocked dummy & - & & - & & $-1.34^{* * * *}$ & $(-2.57)$ & $-1.63^{* * * *}$ & $(-3.24)$ & $-1.82^{* * *}$ & $(-3.62)$ & $-1.54^{* * *}$ & $(-2.82)$ \\
\hline Island dummy & - & & - & & $0.90^{* *}$ & $(2.01)$ & 0.84 & $(1.74)$ & 0.68 & $(1.39)$ & 0.59 & $(1.30)$ \\
\hline Adjacency dummy & - & & - & & $1.25^{*}$ & (1.87) & $1.74^{* * *}$ & $(2.45)$ & $1.64 * *$ & $(2.38)$ & $1.15^{*}$ & (1.56) \\
\hline Dummyagro & $2.18^{* * *}$ & (4.17) & $2.16^{* * *}$ & $(4.79)$ & $2.18^{* * *}$ & $(4.82)$ & $2.14^{* * *}$ & $(4.88)$ & -5.75 & $(-0.84)$ & - & \\
\hline Dummycer & $3.02^{* * *}$ & $(5.92)$ & $3.06^{* * *}$ & $(6.22)$ & $2.99^{* * * *}$ & $(6.24)$ & $2.97^{* * *}$ & $(6.53)$ & -11.86 & $(-1.71)$ & - & \\
\hline Dummyha & -0.53 & $(-0.81)$ & -0.47 & $(-0.79)$ & -0.50 & $(-0.87)$ & -0.49 & $(-0.90)$ & -4.95 & $(-0.56)$ & - & \\
\hline Number of observations & 255 & & 255 & & 255 & & 255 & & 255 & & 255 & \\
\hline$R^{2}$ & 0.33 & & 0.380 & & 0.427 & & 0.493 & & 0.50 & & 0.48 & \\
\hline Adjusted $R_{2}$ & 0.32 & & 0.364 & & 0.401 & & 0.467 & & 0.47 & & 0.45 & \\
\hline $\mathrm{SE}$ of regression & 2.60 & & 2.516 & & 2.442 & & 2.303 & & 2.29 & & 2.29 & \\
\hline Ramsey reset test & $2.74^{*}$ & & $6.09^{* *}$ & & $2.28^{*}$ & & $10.85^{* *}$ & & $8.61^{* * *}$ & & 0.357 & \\
\hline $\begin{array}{l}F \text {-test (equality } \\
\text { of slopes Idist); d.f. }(3,198)\end{array}$ & & & & & & & & & & & $23.92^{* *}$ & \\
\hline
\end{tabular}

Notes: White Heteroskedasticity-Consistent t-values are in brackets. All variables are for the year 2001.***,** and * indicate significance at 1, 5 and $10 \%$ levels respectively. T-statistics are in brackets. The dependent variable is the natural $\log$ of exports in volume. Mode is adummy variable that takes the value one when the good is transported by sea and zero otherwise. All the variables except dummies are in natural logs. 
Table 3. Estimates of export elasticity with respect to transport costs

\begin{tabular}{llll}
\hline & $\begin{array}{l}\text { Transport-cost equation } \\
\alpha_{1} \text { Distance }\end{array}$ & $\begin{array}{l}\text { Trade equation } \\
\beta_{2} \text { Distance }\end{array}$ & $\begin{array}{l}\text { Export elasticities } \\
\tau=\beta_{2} / \alpha_{1}\end{array}$ \\
\hline Agro-industry & 0.61 & -0.94 & -1.52 \\
Ceramics & 0.69 & -0.84 & -1.20 \\
Household appliances & 0.46 & -1.31 & -2.82 \\
Vehicle parts & 0.31 & -1.22 & -3.93 \\
\hline
\end{tabular}

Notes: The point estimates for distance in the transport-cost equation, are from Table 1. The point estimates for distance in the export equation are from Model 6 in Table 2.

\section{Conclusions}

The objective of this article was to investigate the determinants of sectoral transport costs and the role they play in deterring international trade. We estimated a transport-cost equation using data on transportation costs for four sectors obtained from interviews held with Spanish exporters and logistics operators. We also studied the relationship between transport costs and trade, and we estimated an export supply (import demand) model. Our results from the first estimation show that the distance variable behaves differently according to the mode of transport. The infrastructure variable is only significant for lowvalue-added sectors, poor infrastructure leads to a notable increase in transport costs. Inclusion of infrastructure measures improves the fit of the regression in low value-added sectors, corroborating the importance of infrastructure in determining transport costs. Additionally, higher frequency or larger size of the shipments lowers transport costs in all four sectors, indicating the presence of economies of scale.

Our results from the second estimation show that importer income, as expected, has a positive influence $\mathrm{n}$ bilateral trade flows. The distance variable loses significance when infrastructure variables are considered and it is only significant for half of the sectors. The inclusion of distance specific coefficients improves the fit of the trade equation and once the endogeneity of the income variable is considered, distance is clearly significant for high value-added sectors and less significant and with a lower magnitude for low value-added sectors.

The calculation of trade elasticities with respect to transport costs indicates that transport cost have a greater effect on trade flows for high value-added sectors, whereas its influence is significantly lower in the case of low value-added sectors. However, future estimations for sectors and products with different logistic processes will be of interest in order to improve the knowledge of the effects of transportation costs on trade flows under diverse conditions of international transport.

\section{Acknowledgements}

Financial support from Fundación Caja Castellón -Bancaja, Generalitat Valenciana and the Spanish Ministry of Education is gratefully acknowledged (P1-1B2005-33, Grupos 03-151, INTECO; Research Projects GV04B-030, SEJ 2005-01163 and ACOMP06/047). We would also like to thank two anonymous referees and the participants in the 6th INFER Workshop on Economic Policy in Reus (Spain) and in the I International Transport Congress hold in Castellón (Spain) for their comments and suggestions. We thank Elena Sanjuan-Lucas for excellent research assistance.

\section{References}

Baier, S. L. and Bergstrand, J. H. (2001) The growth of world trade: tariffs, transport costs and income similarity, Journal of International Economics, 53, 1-27. 
Bayoumi, T. and Eichengreen, B. (1997) Is regionalism simply a diversion? Evidence from the evolution of the EC and EFTA, in Regionalism versus Multilateral Arrangements (Eds) T. Ito and A. O. Krueger, The University of Chicago Press, Chicago, pp. 161-90.

Deardorff, A. V. (1995) Determinants of bilateral trade: does gravity work in a neoclassic world? National Bureau of Economic Research Working Paper 5377. Cambridge, Massachusetts, USA.

Fink, C., Mattoo, A. and Neagu, I. C. (2002) Trade in international maritime services: how much does policy matter?, World Bank Economic Review, 16, 81-108.

Henderson, J. V., Shalizi, Z. and Venables, A. J. (2001) Geography and development, Journal of Economic Geography, 1, 81-106.

Huang, R. R. (2007) Distance and trade: disentangling unfamiliarity effects and transport cost effects, European Economic Review, Vol. 51(1), Elsevier, pp. 161-81.

Hummels, D. (1999a) Towards a Geography of Trade Costs, Mimeographed Document, University of Chicago.

Hummels, D. (1999b) Have international transportation costs declined? mimeographed Document, University of Chicago.

Hummels, D. (2001) Have international transportation costs declined?, Journal of International Economics, 54, 75-96.

Hummels, D., Ishii, J. and Yi, K.-M. (2001) The nature and growth of vertical specialisation in world trade, Journal of International Economics, 54, 75-96.

Hummels, D. and Lugovskyy, V. (2006) Are matched partner trade statistics a usable measure of transportation costs? Review of International Economics, 14(1), 65-86.

Krugman, P. (1991) Increasing returns and economic geography, Journal of Political Economy, 99, 48399.

Kumar, S. and Hoffmann, J. (2002) Globalization - the maritime nexus, in Handbook of Maritime Economics and Business (Ed.) C. T. Grammenos, LLP, London, pp. 35-62.

Limao, N. and Venables, A. J. (2001) Infrastructure, geographical disadvantage and transport costs, World Bank Economic, 15, 451-79, Review.

Martínez-Zarzoso, I., García-Menendez, L. and Suárez-Burguet, C. (2003) The impact of transport cost on international trade: the case of Spanish ceramic exports, Maritime Economics \& Logistics, 5, 179-98.

Martinez-Zarzoso, I. and Suarez-Burguet, C. (2005). Transport costs and trade: empirical evidence for Latin American imports from the European Union, Journal of International Trade and Economic Development, 14(3), 227-45.

Micco, A. and Pérez, N. (2001) Maritime transport costs and port efficiency, Inter-American Development Bank, Research Working Paper.

Oguledo, V. I. and Macphee, C. R. (1994) Gravity models: a reformulation and an application to discriminatory trade arrangements, Applied Economics, 26, 107-20.

Radelet, S. and Sachs, J. (1998) Shipping costs, manufactured exports and economic growth, mimeographed document, Harvard Institute for International Development, Harvard University, pp. 4142.

Sánchez, R. J., Hoffmann, J., Micco, A., Pizzolitto, G., Sgut, M. and Wilmsmeier, G. (2002) Port efficiency and international trade, in Conference proceedings of International Association of Maritime Economist, annual meeting and conference, Panama, November. 
Venables, A. J. and Limao, N. (2002) Geographical disadvantage: a Hecksscher-Ohlin-von Thunen model of international specialisation, Journal of International Economics, 58, 239-63.

Yeats, A. J. (1977) Do international transport costs increase with fabrication? Some empirical evidence, Oxford Economic Papers, 29, 458-71.

\section{Appendix}

Table A1. Fieldwork: regional distribution of interviews

\begin{tabular}{|c|c|c|c|c|c|c|c|c|}
\hline Sectors & Andalucía & Aragón/La Rioja & Cataluña & $\begin{array}{l}\text { Comunidad } \\
\text { Valenciana }\end{array}$ & $\begin{array}{l}\text { Madrid/ } \\
\text { Castilla La } \\
\text { Mancha }\end{array}$ & Murcia & $\begin{array}{l}\text { País Vasco/ } \\
\text { Navarra/ } \\
\text { Cantabria }\end{array}$ & Total \\
\hline Agro-industry (Xc) & 10 & 3 & 9 & 11 & 15 & 14 & 2 & 64 \\
\hline Ceramic tiles (Xc) & 0 & 0 & 2 & 31 & 0 & 0 & 0 & 33 \\
\hline Vehicle parts (Xc) & 0 & 6 & 13 & 1 & 4 & 0 & 8 & 32 \\
\hline $\begin{array}{l}\text { House hold } \\
\text { appliances (Xc) }\end{array}$ & 0 & 1 & 23 & 0 & 0 & 0 & 7 & 31 \\
\hline Total Xc & 10 & 10 & 47 & 43 & 19 & 14 & 17 & 160 \\
\hline Agro-industry (Ff) & 3 & 1 & 4 & 8 & 4 & 2 & 0 & 22 \\
\hline Ceramic tiles (Ff) & 1 & 1 & 1 & 16 & 2 & 1 & 0 & 22 \\
\hline Vehicle parts (Ff) & 3 & 4 & 5 & 4 & 8 & 0 & 0 & 24 \\
\hline $\begin{array}{l}\text { House hold } \\
\text { appliances (Ff) }\end{array}$ & 2 & 1 & 3 & 0 & 4 & 0 & 0 & 10 \\
\hline Total Ff & 9 & 7 & 13 & 28 & 18 & 3 & 0 & 78 \\
\hline Total & 19 & 17 & 60 & 71 & 37 & 17 & 17 & 238 \\
\hline
\end{tabular}

Note: Xc denotes export companies and Ff denotes freight forwarders.

Table A2. Variable averages

\begin{tabular}{|c|c|c|c|c|c|c|c|c|}
\hline \multirow[b]{2}{*}{ Variables } & \multicolumn{2}{|c|}{$\begin{array}{l}\text { Sector 1: } \\
\text { Agro-industry }\end{array}$} & \multicolumn{2}{|c|}{$\begin{array}{l}\text { Sector 2: } \\
\text { Ceramic tiles }\end{array}$} & \multicolumn{2}{|c|}{$\begin{array}{l}\text { Sector 3: } \\
\text { Vehicle parts }\end{array}$} & \multicolumn{2}{|c|}{$\begin{array}{l}\text { Sector } 4 \text { : } \\
\text { Household } \\
\text { appliances }\end{array}$} \\
\hline & Road & Sea & Road & Sea & Road & Sea & Road & Sea \\
\hline $\begin{array}{l}\text { Frequency of Shipments } \\
\text { (No. of shipments per annum) }\end{array}$ & 109.60 & 125.30 & 962.90 & 205.83 & 141.52 & 47.42 & 184.92 & 78.75 \\
\hline Average size of shipments $\left(\mathrm{m}^{3}\right)$ & 124.17 & 358.21 & 942.02 & 129.76 & 64.90 & 247.45 & 61.09 & 51.80 \\
\hline $\begin{array}{l}\text { Frequency of shipments } \\
\text { (No. of shipments per annum) }\end{array}$ & 101.92 & 68.51 & 1005.40 & 124.22 & 79.04 & 42.23 & 173.98 & 69.64 \\
\hline $\begin{array}{l}\text { Average size of shipments }\left(\mathrm{m}^{3}\right) \\
\text { export companies }\end{array}$ & 51.03 & 312.55 & 83.89 & 74.42 & 30.54 & 330.72 & 55.05 & 53.58 \\
\hline Distance $(\mathrm{km})$ & 1759.72 & 3074.15 & 1640.50 & 3433.68 & 1527.41 & 1538.83 & 1389.43 & 2379.66 \\
\hline Transport cost (Euro/Tm) & 109.84 & 66.83 & 82.16 & 53.89 & 285.22 & 77.21 & 238.27 & 113.06 \\
\hline Transit time (hours) & 77.05 & 181.70 & 59.77 & 188.30 & 65.67 & 118.11 & 56.25 & 153.20 \\
\hline Delayed shipments $(\%)$ & 0.47 & 4.18 & 0.95 & 1.13 & 2.76 & 9.35 & 2.93 & 5.60 \\
\hline Average delay (hours) & 1.20 & 9.26 & 3.24 & 14.33 & 6.16 & 8.66 & 4.71 & 16.29 \\
\hline Shipments damaged or lost $(\%)$ & 0.98 & 0.28 & 0.29 & 0.44 & 0.10 & 2.35 & 0.98 & 0.00 \\
\hline $\begin{array}{l}\text { Average damage ( } \% \text { of } \\
\text { total value of shipment) }\end{array}$ & 0.23 & 3.07 & 0.16 & 0.62 & 0.40 & 3.71 & 3.59 & 0.00 \\
\hline Consolidated shipments (\%) & 31.03 & 12.18 & 58.82 & 20.25 & 77.14 & 43.26 & 46.21 & 31.67 \\
\hline $\begin{array}{l}\text { Transport restrictions } \\
\text { (no. of days per year) }\end{array}$ & 107.39 & 0.00 & 104.07 & 0.00 & 110.93 & 0.00 & 106.29 & 0.00 \\
\hline $\begin{array}{l}\text { Shipments delayed } \\
\text { due to restrictions (\%) }\end{array}$ & 0.04 & 0.00 & 0.00 & 0.00 & 0.00 & 0.00 & 0.00 & 0.00 \\
\hline $\begin{array}{l}\text { Average delay due to } \\
\text { restrictions (hours) }\end{array}$ & 0.43 & 0.00 & 0.00 & 0.00 & 0.00 & 0.00 & 0.00 & 0.00 \\
\hline
\end{tabular}


Table A3. Data collection

\begin{tabular}{lcc}
\hline Sector & Exporters & Logistic operators \\
\hline Fieldwork: number of interviews & 33 & 22 \\
Agro-industry & 64 & 22 \\
Ceramic tiles & 32 & 24 \\
Vehicle parts & 31 & 10 \\
Household appliances & 160 & 78 \\
Total & & \\
\hline
\end{tabular}

\section{Interview process}

Most interviews were personal interviews arranged previously with logistics managers and/or import/ export managers in exporting companies as well as logistic operators and freight forwarders. The sample was selected according to a previously designed segmentation of the market. The objective of this sampling procedure was to undertake the fieldwork with a highly representative sample of the Spanish exporting industry, in terms of geographical location, company size and exported commodities. A structured questionnaire was prepared in advance and detailed questions were asked concerning the commodity exported, the most commonly covered transport routes, the transport mode selected for each route, the specific characteristics (cost, transit time, frequency) of the transport mode chosen and its alternative mode. Currently, the Institute of International Economics and the Foundation Valenciaport are presently in the process of building a more complete sectoral transport-costs database.

Table A4. Destination countries

\begin{tabular}{llll}
\hline Algeria & France & Netherlands & Turkey \\
Austria & Germany & New Zealand & Ukraine \\
Byelorussia & Greece & Norway & \\
Belgium & Hungary & Poland & \\
Bosnia-Herzegovina & Ireland & Portugal \\
Bulgaria & Israel & Rumania \\
Croatzia & Italy & Russia & \\
Czech Republic & Latvia & Saudi Arabia & \\
Cyprus & Libya & Slovak Republic \\
Denmark & Lithuania & Syria & \\
Egypt & Luxembourg & Sweden & \\
Estonia & Malta & Switzerland \\
Finland & Morocco & Tunisia & \\
\hline
\end{tabular}


Table A5. Sectoral trade HS codes

\begin{tabular}{|c|c|c|}
\hline Sectors & Codes & Product description \\
\hline \multirow[t]{28}{*}{ Agroal } & 1001 & Wheat and meslin \\
\hline & 1002 & Rye \\
\hline & 1003 & Barley \\
\hline & 1004 & Oats \\
\hline & 1005 & Maize (corn) \\
\hline & 1006 & Rice \\
\hline & 1007 & Grain sorghum \\
\hline & 1008 & Buckwheat, millet and canary seed; other cereals \\
\hline & 1101 & Wheat or meslin flour \\
\hline & 1102 & Cereal flour other than of wheat or meslin \\
\hline & 1103 & Cereal groats, meal or pellets \\
\hline & 1104 & $\begin{array}{l}\text { Cereal grains otherwise worked (e.g. hulled, rolled, flaked, pearled, sliced or } \\
\text { kibbled), except rice of heading 1006; germ of cereals, whole, rolled, flaked or } \\
\text { ground }\end{array}$ \\
\hline & 1105 & Flour, meal, powder, flakes, granules and pellets of potatoes \\
\hline & 1106 & $\begin{array}{l}\text { Flour, meal and powder of the dried leguminous vegetables of heading } 0713 \text {, of sago } \\
\text { or of roots or tubers of heading } 0714 \text { or of the products of chapter } 8\end{array}$ \\
\hline & 1107 & Malt, whether or not roasted \\
\hline & 1108 & Starches; inulin \\
\hline & 1109 & Wheat gluten, whether or not dried \\
\hline & 1509 & Olive oil and its fractions, whether or not refined, but not chemically modified \\
\hline & & $\begin{array}{l}\text { Other oils and their fractions, obtained solely from olives, whether or not refined, } \\
\text { but not chemically modified, including blends of these oils with oils or fractions of } \\
\text { heading no. } 15.09\end{array}$ \\
\hline & 1512 & $\begin{array}{l}\text { Sunflower-seed, safflower or cotton-seed oil and fractions thereof, whether or not } \\
\text { refined, but not chemically modified }\end{array}$ \\
\hline & 2001 & $\begin{array}{l}\text { Vegetables, fruit, nuts and other edible parts of plants, prepared or preserved by } \\
\text { vinegar or acetic acid }\end{array}$ \\
\hline & 2002 & Tomatoes prepared or preserved otherwise than by vinegar or acetic acid \\
\hline & 2004 & $\begin{array}{l}\text { Other vegetables prepared or preserved otherwise than by vinegar or acetic acid, } \\
\text { frozen, other than products of heading } 2006\end{array}$ \\
\hline & 2005 & $\begin{array}{l}\text { Other vegetables prepared or preserved otherwise than by vinegar or acetic acid, not } \\
\text { frozen, other than products of heading no } 2006\end{array}$ \\
\hline & 2006 & $\begin{array}{l}\text { Vegetables, fruit, nuts, fruit-peel and other parts of plants, preserved by sugar } \\
\text { (drained, glace or crystallized). }\end{array}$ \\
\hline & 2007 & $\begin{array}{l}\text { Jams, fruit jellies, marmalades, fruit or nut puree and fruit or nut pastes, obtained by } \\
\text { cooking, whether or not containing added sugar or other sweetening matter }\end{array}$ \\
\hline & 2204 & $\begin{array}{l}\text { Wine of fresh grapes, including fortified wines; grape must other than that of heading } \\
\text { no } 2009\end{array}$ \\
\hline & 2205 & $\begin{array}{l}\text { Vermouth and other wine of fresh grapes flavoured with plants or aromatic } \\
\text { substances }\end{array}$ \\
\hline Ceramics & 6907 & $\begin{array}{l}\text { Unglazed ceramic flags and paving. Hearth or wall tiles; unglazed ceramic mosaic } \\
\text { cubes }\end{array}$ \\
\hline & 6908 & Glazed ceramic flags and paving, hearth or wall tiles; glazed ceramic mosaic cubes \\
\hline House hold appliances & 8418 & Refrigerators, freezers and other refrigerating or freezing equipment \\
\hline & 8422 & Dish washing machines; machinery for cleaning or drying bottles or other containers. \\
\hline & 8423 & $\begin{array}{l}\text { Weighing machinery (excluding balances of a sensitivity of } 5 \mathrm{cg} \text { or better), including } \\
\text { weight operate }\end{array}$ \\
\hline & 8450 & $\begin{array}{l}\text { Household or laundry-type washing machines, including machines which both wash } \\
\text { and dry }\end{array}$ \\
\hline & 8509 & Electro-mechanical domestic appliances, with self-contained electric motor \\
\hline & 8516 & $\begin{array}{l}\text { Electric instantaneous or storage water heaters and immersion heaters; electric space } \\
\text { heating apparatus }\end{array}$ \\
\hline & 8519 & $\begin{array}{l}\text { Turntables (record-decks), record-players, cassette-players and other sound repro- } \\
\text { ducing apparatus }\end{array}$ \\
\hline & 8520 & Magnetic tape recorders and other sound-recording apparatus \\
\hline & 8521 & Video recording or reproducing apparatus \\
\hline & 8525 & Transmission apparatus for radio-telephony, radio-broadcasting or television \\
\hline & 8528 & $\begin{array}{l}\text { Television receivers (including video monitors and video projectors), whether or not } \\
\text { combined }\end{array}$ \\
\hline Vehicles & 8708 & Parts and accessories of the motor vehicles of headings 87.01 to 87.05 . \\
\hline
\end{tabular}

